\title{
LEVEL OF OVERALL HEMOSTASIS POTENTIAL IN DONOR AND PATIENT PLASMA IN PATHOLOGY
}

\author{
L. V. PYROGOVA, T. M. CHERNYSHENKO, I. N. KOLESNIKOVA, T. N. PLATONOVA, \\ G. K. BEREZNITSKY, Y. M. MAKOGONENKO, E. V. LUGOVSKOY
}

Palladin Institute of Biochemistry, National Academy of Sciences of Ukraine, Kyiv; e-mail:ymakogonenko@gmail.com

Coagulation potential $(\mathrm{CP})$, overall hemostasis potential $(\mathrm{OHP})$ and fibrinolysis potential $(\mathrm{FP})$ in plasma of donors and patients with myocardial infarction (MI), stroke (St) and hip joint diseases (HJD) have been investigated using M. Blomback's global hemostasis assay. Plasma samples of the patients were analyzed with APTT reagent in the presence or absence of $t-P A$. It was found that the ratio of values of $C P, O H P$ and FP in plasma of patients to those of donors plasma were 78, 60 and 123\% at MI; 157, 155 and 162\% at St; 128,131 and $124 \%$ at HJD. CP to FP ratio that indicated balance between coagulation and fibrinolytic systems activities were 4.13, 2.5, 4.0 and 4.26 in plasma of donors and MI, St and HJD patients, respectively. These results are evidence of increased fibrinolytic activity in plasma of MI patients. Lag-periods of plasma clotting of MI, St and HJD patients were prolonged by 2.3, 7.2 and 1.5-fold, respectively. Pearson's correlation analysis between parameters, obtained in vitro studies using global hemostasis assay, and concentrations of the molecular markers (soluble fibrin and D-dimer), which formed in vivo in plasma of MI, St and HJD patients, did not reveal any relationship between them.

Key words: hemostasis potential of blood plasma, soluble fibrin, D-dimer.

A global hemostasis assay developed by M. Blomback [1-8] is one of the methods of general characteristic of the plasma hemostatic system of donors and patients. It enables characterization of the functional activity of the coagulation and fibrinolytic systems, the relationship with each other as well as with concentrations of other hemostasis markers in patients' blood plasma. In particular, the method has been used to study the effect of different concentrations of FVIIa on global hemostasis and on TAFI (thrombin activated fibrinolysis inhibitor) dependent fibrinolysis in the blood plasma of patients with deficiency of FII, FV, FVII, FVIII, FIX, FXI and FXII [1]. The authors believe that the method can be used for evaluation of the hemostatic effect of FVIIa, as well as for treatment with this factor of patients with hemophilia A and high level of anti-FVIIIa antibodies [2]. It has been found that in patients with FXIIa deficiency the overall hemostasis potential and coagulation potential were increased, though fibrinolytic potential was significantly reduced, indicating higher risk of thrombosis [3]. Another study reported that in patients with deep vein thrombosis associated with resistance to activated protein $\mathrm{C}$, an increased procoagulant ac- tivity and an increased level of overall hemostasis potential were observed [4]. The study on the effect of direct thrombin inhibitors such as dabigatran and argatroban on plasma clotting using the global hemostasis assay showed that these inhibitors reduce the coagulation potential and enhance the fibrinolytic potential of blood plasma [5]. The assay was also used to examine the blood plasma of patients with various diseases accompanied by hemostatic system disorders, namely arterial and venous thromboembolism, coronary artery disease, ischemic heart disease, autoimmune diseases, etc. [9-14].

In this paper we present the results of determination of the CP, OHP and FT values, as well as the relationship between these indicators and their relationship with the concentrations of such hemostatic molecular markers as soluble fibrin and D-dimer in the plasma of donors and patients with hip joints diseases, myocardial infarction and stroke immediately after admission to the hospital.

\section{Materials and Methods}

APTT (activated partial thromboplastin time) reagent (RENAM, Russia), recombinant tissue plasminogen activator (t-PA) (Boehringer Ingelheim, 
Germany) were used in the study. Blood of donors and patients were sampled in $3.8 \%$ sodium citrate (1 part of sodium citrate and 9 parts of blood, $\mathrm{pH}$ 7.4). Patients' blood sampling was performed before treatment. Plasma was separated from blood cells within $1 \mathrm{~h}$ after blood sampling by centrifugation at $3000 \mathrm{~g}$ for $20 \mathrm{~min}$. Plasma aliquots were stored at $-20^{\circ} \mathrm{C}$.

Hemostasis potential in plasma was determined using spectrophotometry recording the absorbance by the fibrin clot at $405 \mathrm{~nm}$ on microreader Multiscan (Finland). The clots were formed in wells of microplate, to which the following reagents were added sequentially: 0.05 M HEPES buffer ( $\mathrm{pH} 7.4$ ), containing $0.15 \mathrm{M} \mathrm{NaCl}, 70 \mu \mathrm{l}$ blood plasma, t-PA to a final concentration of $75 \mathrm{IU} / \mathrm{ml}$ and APTT reagent. The plasma clotting was initiated by adding of $25 \mathrm{mM} \mathrm{CaCl}_{2}$. The final reaction volume was $300 \mu \mathrm{l}$. OHP is characterized by the area under the curve of clot turbidity from the initiation point of plasma coagulation until the complete clot degradation in the presence of t-PA. CP is the area under the curve of clot formation from plasma coagulation initiation until a moment of the complete clot degradation in the absence of t-PA. FP is the difference between the values of $\mathrm{CP}$ and OHP. All values are expressed in units of absorbance multiplied by the time in seconds (a.u.×s) [14].

The concentrations of fibrinogen, soluble fibrin and $\mathrm{D}$ dimer in blood plasma were determined by an enzyme immunoassay using the test systems developed at the Palladin Institute of Biochemistry of NAS of Ukraine [15]. Statistical analysis was performed using standard Excel software. Average values and their standard deviation were calculated, and correlation pair analysis was performed.

\section{Results and Discussion}

To characterize the hemostatic system in blood plasma of donors and patients, we determined parameters of blood coagulation curve that describe the coagulation process on the whole and its main stages [16]. The plasma ability to form and degrade the clot in the presence of APTT reagent and t-PA was evaluated by assessment of the hemostasis potential, which comprises three components, namely the $\mathrm{CP}$ that characterizes the work of the intrinsic pathway of the coagulation cascade; FP that characterizes the ability of the fibrinolytic component of the system to degrade the clot; OHP that characterizes the ability of the hemostasis system to maintain the balance between the formation and degradation (lysis) of blood plasma clot. The separate stages of coagulation process were determined by such parameters as lag period, which indicates the rate of coagulation cascade activation, formation of thrombin and protofibrils; the maximum rate of increase in turbidity, which indicates the rate of protofibrils lateral association and fibril formation; the clot turbidity that reflects the clot fiber thickness [17]. Moreover, the ratio between the values of $\mathrm{CP}$, OHP and FP as well as the concentrations of hemostasis molecular markers (fibrinogen, soluble fibrin, D-dimer) were presented in this study. The average values of studied parameters for donors' blood plasma are shown in Table 1.

Typical curves for the blood plasma coagulation of donors are shown in Fig. 1.

It is seen that the curves on the interval of plasma clotting coincide for both systems. At that clot turbidity quickly reached a maximum and in the absence of t-PA did not further change, that is, clot formation was completed. Since the rate of protofibril lateral association and fibril formation did not alter in the presence of t-PA, the formation of fibrinolytic enzyme plasmin, which would degrade the fibrin polymer, did not occur during the interval of reaching the plateau of the curve (Fig. 1) [18]. It is known that the protofibrils binding with fibril competes with the binding of plasminogen $(\mathrm{Pg})$ and t-PA with the fibril surface, and hence Pg and t-PA

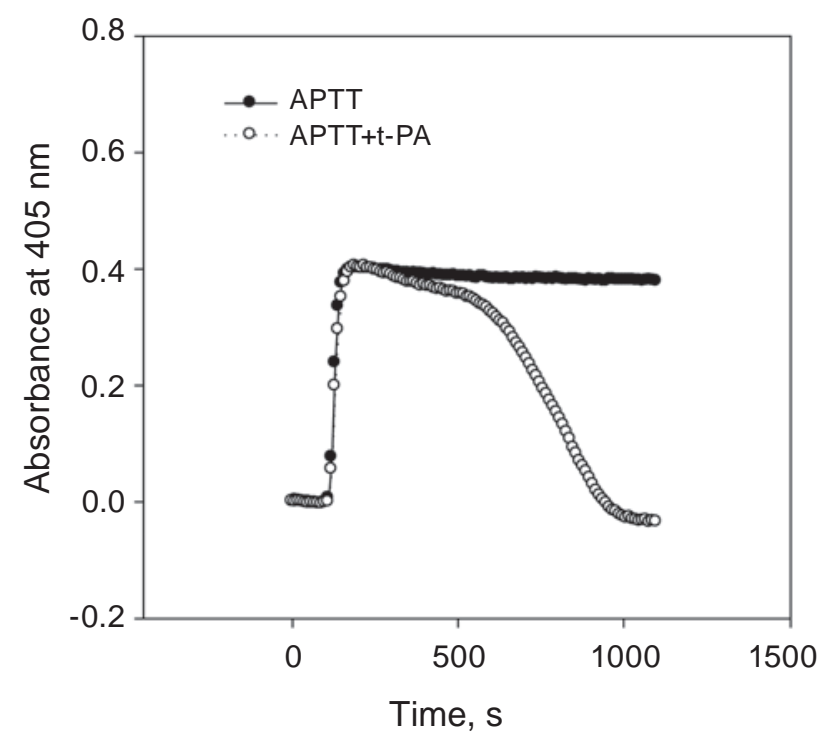

Fig. 1. Typical curves for the blood plasma coagulation of donors induced by APTT reagent in the presence and absence of $t-P A$ 
are observed only on the fibril surface of the formed clot [19]. After reaching plateau, which indicates the completion of the fibril clot formation, activation of the fibrinolytic system and degradation of clot structure begin. However, the turbidity decreased slowly owing to cleavage of mainly fibrin $\alpha \mathrm{C}$-fragments at this stage $[20,21]$. After the C-terminal lysine appeared on fibrin molecules, the Pg activation enhanced significantly and the clot degradation accelerated and quickly completed (Fig. 1) [22, 23].

The curves obtained for plasma clot formation and degradation in the presence of t-PA upon all studied diseases had similar shape with certain differences.

First of all, they differ in the duration of the lag period, which is extended upon all studied diseases. Thus, at stroke the rate of coagulation pathway activation as well as protofibril formation slowed down 7-fold (Fig. 3, Table 1). This might be associated with the release of heparin in the bloodstream and the formation of its complex with antithrombin III. It was also observed that the maximum clot turbidity increased 1.5-fold upon stroke. The maximum clot turbidity at myocardial infarction was on the average $25 \%$ smaller in the presence of t-PA than that in the

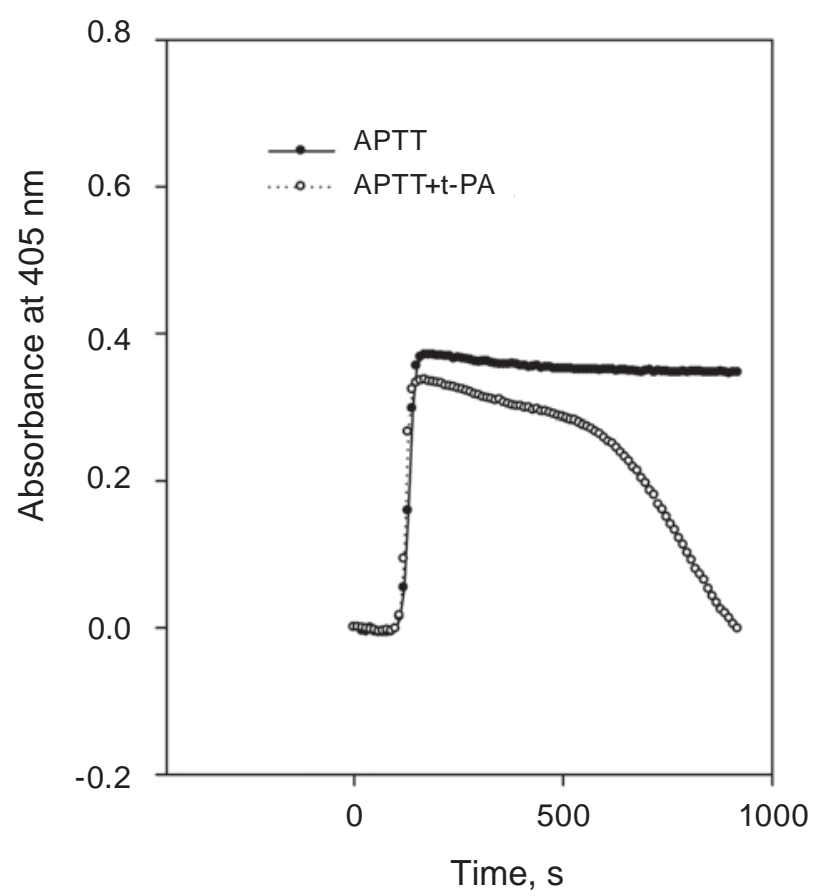

Fig. 2. Typical curves for the blood plasma coagulation induced by APTT reagent in the presence and the absence of $t-P A$ of patients with a myocardial infarction

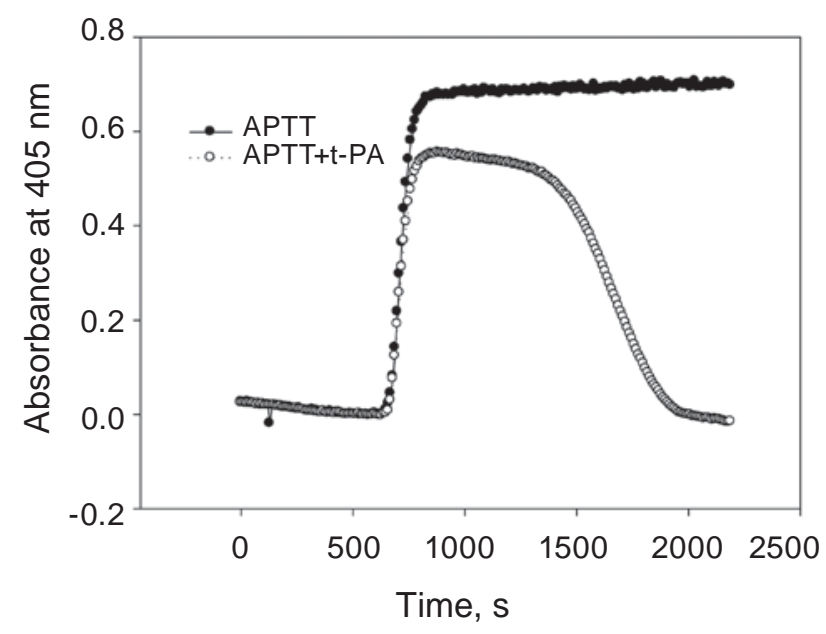

Fig 3. Curves for the blood plasma coagulation induced by APTT reagent in the presence and the $a b-$ sence of $t-P A$ of patients with a stroke

absence of t-PA as well as in donors' plasma (Fig. 2, Table 1). The curves for blood plasma coagulation in patients with HJD and donors did not differ from each other in shape (Fig. 4 and Fig. 1). The clot turbidity in the blood plasma of these patients, compared to the norm, was smaller (Table 1). Clot half-lysis time increased upon all studied diseases that indicated an increase in the plasma fibrinolytic inhibitors concentration (Table 1).

Curves for alterations in clot turbidity during the blood plasma clotting were used to determine general parameters of the process, namely hemostasis potential and its components such as $\mathrm{CP}$, OHP and FP which indicate formation rate, life time and fibrin clot lysis rate in blood plasma in vitro.

Blood plasma samples (25 samples) of patients with myocardial infarction who had just been admitted to the hospital were examined. It was found that CP and OHP reduced by 78 and $60 \%$, respectively, compared to donors, and FP was $123 \%$ of the norm (Table 1). This indicates that in these patients the balance between coagulation and fibrinolysis shifted towards the latter. Lag period of plasma coagulation increased, indicating the inhibition of thrombin formation rate in the intrinsic pathway in vitro. Level of the hemostasis molecular markers in vivo was found to be: Fg remained within the normal range, the concentrations of soluble fibrin and D-dimer increased by 57 and $72 \%$, respectively.

The potentials values of plasma hemostatic system in patients with a stroke. Blood plasma samples of patients with a stroke (10 samples) were studied. 
Table 1. Hemostasis potential, coagulation parameters and concentrations of fibrinogen, soluble fibrinogen and D-dimer in blood plasma activated by APTT reagent of donors $(n=10)$ and patients. $A-$ in the absence of $t-P A ; B$ - in the presence of $t-P A ; C$ - hemostasis potential parameters at norm and diseases; $D$ molecular markers concentrations

A

\begin{tabular}{lcc|c}
\hline \multicolumn{1}{c}{ Blood plasma } & T, s & $\alpha$, a.u./s & H, a.u. \\
\hline Donors & $110 \pm 23$ & $0.0041 \pm 0.0010$ & $0.39 \pm 0.02$ \\
Patients with infarction & $256 \pm 136$ & $0.0069 \pm 0.0046$ & $0.34 \pm 0.13$ \\
Patients with stroke & $793 \pm 264$ & $0.0061 \pm 0.0036$ & $0.58 \pm 0.12$ \\
Patients with HJD & $162 \pm 104$ & $0.0047 \pm 0.0033$ & $0.26 \pm 0.08$ \\
\hline
\end{tabular}

$\boldsymbol{B}$

\begin{tabular}{l|c|c|c|c}
\hline \multicolumn{1}{c}{ Blood plasma } & T, s & $\alpha$, a.u./s & H, a.u. & L, s \\
\hline Donors & $105 \pm 20$ & $0.0038 \pm 0.0011$ & $0.385 \pm 17$ & $954 \pm 45$ \\
Patients with infarction & $238 \pm 127$ & $0.0055 \pm 0.0044$ & $0.256 \pm 0.08$ & $1004 \pm 354$ \\
Patients with stroke & $724 \pm 171$ & $0.0051 \pm 0.0026$ & $0.526 \pm 12$ & $1709 \pm 370$ \\
Patients with HJD & $186 \pm 87$ & $0.0065 \pm 0.0019$ & $0.314 \pm 0.07$ & $1433 \pm 81$ \\
\hline
\end{tabular}

C

\begin{tabular}{|c|c|c|c|c|c|c|}
\hline Blood plasma & $\mathrm{CP}$, a.u. $\times \mathrm{s}$ & OHP, a.u. $\times_{\mathrm{s}}$ & FP, a.u. $\times$ s & $\mathrm{CP} / \mathrm{OHP}$ & CP/FP & OHP/FP \\
\hline Donors & $376 \pm 13$ & $285 \pm 19$ & $91 \pm 7$ & $1.32 \pm 0.12$ & $4.13 \pm 0.09$ & $3.13 \pm 0.11$ \\
\hline $\begin{array}{l}\text { Patients with } \\
\text { infarction }\end{array}$ & $281 \pm 168$ & $170 \pm 65$ & $112 \pm 42$ & $1.65 \pm 0.63$ & $2.51 \pm 1.32$ & $1.52 \pm 1.24$ \\
\hline $\begin{array}{l}\text { Patients } \\
\text { with stroke }\end{array}$ & $590 \pm 193$ & $443 \pm 117$ & $148 \pm 90$ & $1.33 \pm 0.19$ & $4.0 \pm 1.93$ & $3.0 \pm 1.93$ \\
\hline $\begin{array}{l}\text { Patients } \\
\text { with HJD }\end{array}$ & $482 \pm 153$ & $374 \pm 75$ & $113 \pm 112$ & $1.28 \pm 0.17$ & $4.26 \pm 1.49$ & $3.3 \pm 1.29$ \\
\hline
\end{tabular}

D

\begin{tabular}{l|c|c|c}
\hline \multicolumn{1}{c|}{ Blood plasma } & Fibrinogen, $\mathrm{mg} / \mathrm{ml}$ & Soluble fibrin, $\mu \mathrm{g} / \mathrm{ml}$ & $\mathrm{DD}, \mathrm{ng} / \mathrm{ml}$ \\
\hline Donors & $2.8 \pm 0.36$ & $2.6 \pm 0.67$ & $62 \pm 16$ \\
Patients with infarction & $3.0 \pm 0.83$ & $4.0 \pm 2.3$ & $107 \pm 77$ \\
Patients with stroke & ND & $3.7 \pm 0.7$ & $171 \pm 157$ \\
Patients with HJD & $3.5 \pm 1.1$ & $4.1 \pm 2.8$ & $179 \pm 135$ \\
\hline
\end{tabular}

$\mathrm{T}$ - lag period of coagulation; $\alpha$ - the rate of protofibril lateral association; $\mathrm{H}$ - maximum fibrin clot absorbance; $\mathrm{L}-$ clot half-lysis time; CP, OHP, FP - blood plasma coagulation potential, overall hemostasis potential, fibrin potential; DD D-dimer of fibrin.

In these patients, $\mathrm{CP}$ and OHP were greater than that in donors by 57 and 55\%, respectively (Table 1). FP increased by $63 \%$. Moreover, a significant almost 7-fold increase in the lag period, compared to control plasma, was observed. Upon this disease we observed a paradoxical situation in which the inhibition of activation of the coagulation intrinsic pathway, accompanied by a decrease in thrombin concentra- tion, led to an increase in the rate of fibrin clot formation as well as to significant increase in the clot turbidity and the time of its existence, despite the increase in the plasma FP (Table 1). This situation might be related to an increase in inhibitor concentrations in the intrinsic pathway of coagulation that inhibits the thrombin formation. At a lower concentration of thrombin, longer fibrin protofibrils, which 


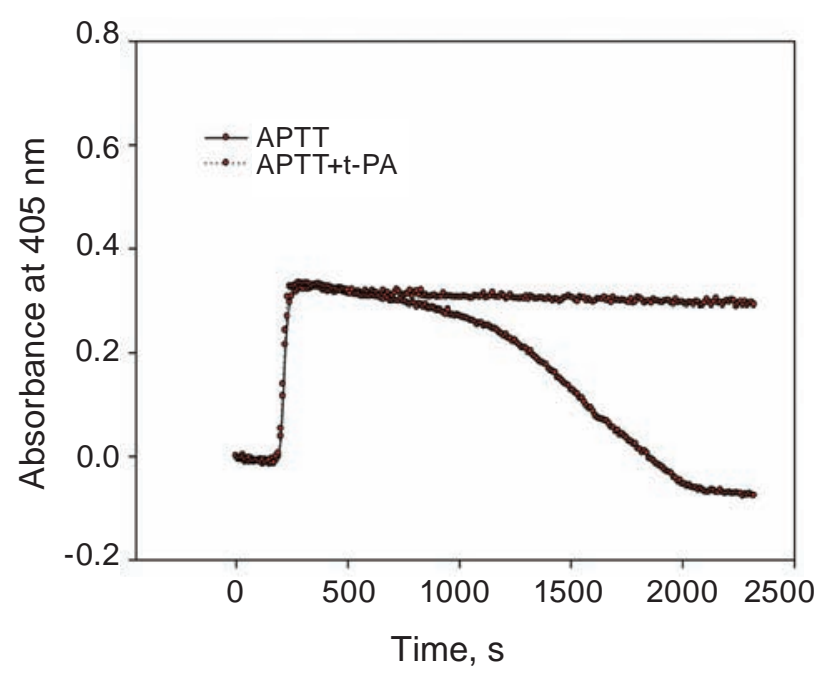

Fig. 4. Typical curves for the blood plasma coagulation induced by APTT reagent in the presence and absence of t-PA of patients with hip joint disease

are laterally associated with a higher rate, are formed [24]. An increase in the maximum clot turbidity is obviously related to the inclusion of plasma proteins such as fibronectin, von Willebrand factor, albumin to the clot $[25,26]$. On the other hand, analysis of the ratio between $\mathrm{CP}$ and $\mathrm{FP}$ revealed that the balance between coagulation and fibrinolysis in patients approached normal physiological values, 4.58 and 4.13, respectively. The level of soluble fibrin was higher by $42 \%$ than the norm, whereas the level of $\mathrm{D}$ dimer was higher by $274 \%$ compared to the norm that indicates the high activity of blood plasma fibrinolysis in vivo.

The plasma hemostasis potentials in patients with hip joint disease. Blood plasma samples (8 samples) of patients with HJD were investigated. It was found that $\mathrm{CP}$ and OHP values were by 28 and $31 \%$ higher than normal values. FP increased by $24 \%$. However, the $\mathrm{CP} / \mathrm{FP}$ ratio that characterizes the balance between coagulation and fibrinolytic systems shifted significantly toward the coagulation system by $68 \%$ compared to the norm. Fibrinogen level was in the normal range. Though, the level of soluble fibrin was slightly (by $27 \%$ ) higher than normal value, and D-dimer was higher by $85 \%$ indicating that the fibrinolytic system activity is sufficient for maintaining a balance between these systems in vivo.

The correlation between the hemostasis parameters and the concentrations of the hemostasis markers. The two groups of the hemostatic system parameters, which had been obtained in two experimental systems, were studied. Blood plasma was one of the systems, in which parameters of the fibrin clot formation and degradation in vitro under the influence of APTT reagent in the presence or absence of t-PA were studied. In another system, hemostasis molecular markers that were formed in blood plasma in vivo and characterized the hemostasis state of donors or patients were studied using immunochemical test-systems [15]. Point of interest was to study the relationship between the parameters within each system as well as between these two systems. The revealing of such connection would allow characterization of the state of homeostasis in vivo based on the parameters of the clot formation process in the blood plasma in vitro. The values of Pearson's linear correlation coefficients for a pair of parameters, the relationships between which are not random (the c.c./c.cor. ratio $\geq 3.0$ ) are represented in Table 2.

A correlation analysis of the plasma parameter values in patients with MI in vitro at plasma activation by APTT reagent revealed the closest relationship between the following parameters: CP-OHP, CP-FP, OHP-H, CP-H, where the correlation coefficients were $0.97,0.82,0.92$ and 0.84 , respectively. The correlations between the parameters of CPOHP and OHP-H are illustrated in Fig. 5. Weaker relationship was observed between $\mathrm{FP}-\mathrm{H}$ and $\mathrm{CP}-\alpha$, OHP- $\alpha$, the correlation coefficients were 0.6 and $0.74,0.70$, respectively. The first value indicates a weaker relation between FP and the clot turbidity. The correlation coefficient for the pair $\mathrm{CP}$ and $\mathrm{OHP}$ demonstrates that these potentials are more related to the clot turbidity than to the rate of the protofibril lateral association at the clot formation. Among the hemostasis blood plasma molecular markers determined by immunochemical method, the correlation between Fg and soluble fibrin was revealed. The correlation between concentrations of fibrinogen and D-dimer was not observed. The obtained value for correlation coefficient between the concentrations of soluble fibrin and D-dimer did not reliably indicate a relationship between these parameters. The relation between system parameters in vitro and molecular markers that are formed in vivo were also not revealed.

Analysis of correlation between plasma parameters of patients with St and HJD revealed, similar to MI patients, the relationship between values of the parameters in the plasma samples activated by APTT reagent in vitro (Table 2 and Fig. 6). 
Table 2. Correlation coefficients for plasma hemostasis parameters of donors and patients with MI, St and $H J D$, which indicate a non-random relationship between them

\begin{tabular}{|c|c|c|c|c|}
\hline Disease & \multicolumn{2}{|c|}{ Hemostasis parameter } & Correlation coefficient & Correlation correction \\
\hline \multirow[t]{10}{*}{ MI } & $\mathrm{CP}$ & OHP & 0.97 & $>30$ \\
\hline & $\mathrm{CP}$ & FP & 0.82 & 10.9 \\
\hline & OHP & FP & 0.64 & 4.6 \\
\hline & OHP & $\mathrm{H}$ & 0.92 & 26.3 \\
\hline & $\mathrm{CP}$ & $\mathrm{H}$ & 0.84 & 12.1 \\
\hline & $\mathrm{OHP}$ & $\alpha$ & 0.74 & 6.9 \\
\hline & $\mathrm{CP}$ & $\alpha$ & 0.70 & 5.7 \\
\hline & FP & $\mathrm{H}$ & 0.60 & 3.9 \\
\hline & Fg & S.f. & 0.62 & 4.8 \\
\hline & S.f. & $\mathrm{DD}$ & 0.52 & 3.02 \\
\hline \multirow[t]{6}{*}{ St } & $\mathrm{CP}$ & OHP & 0.98 & $>30.6$ \\
\hline & $\mathrm{CP}$ & FP & 0.71 & 13.7 \\
\hline & FP & $\mathrm{H}$ & 0.95 & 30.6 \\
\hline & $\mathrm{CP}$ & $\mathrm{H}$ & 0.95 & 26.9 \\
\hline & OHP & $\mathrm{H}$ & 0.93 & 19.6 \\
\hline & $\mathrm{T}$ & $\alpha$ & 0.76 & 5.1 \\
\hline \multirow[t]{6}{*}{ HJD } & $\mathrm{CP}$ & OHP & 0.98 & $>25$ \\
\hline & $\mathrm{CP}$ & FP & 0.92 & 15.5 \\
\hline & OHP & FP & 0.81 & 6.2 \\
\hline & OHP & $\mathrm{H}$ & 0.95 & 25.1 \\
\hline & $\mathrm{CP}$ & $\mathrm{H}$ & 0.93 & 18.8 \\
\hline & OHP & $\alpha$ & 0.83 & 7.3 \\
\hline
\end{tabular}

S.f. - soluble fibrin; Fg - fibrinogen

Concentrations of molecular markers formed in blood plasma in vivo altered independently. Correlations between the plasma coagulation parameters in the presence of APTT reagent and concentrations of hemostasis molecular markers in vivo were also not found.

Thus, the study of hemostasis potential in plasma samples of donors and patients with MI, St and HJD showed that the blood plasma OHP value in MI patients decreased 1.7 times, while in patients with St and HJD increased 2.1 and 1.7 times, respectively
(Table 1). A similar tendency was also observed for the blood plasma CP. The blood plasma FP increased upon all diseases.

However, $\mathrm{CP} / \mathrm{FP}$ ratio, which reflects the balance between coagulation and fibrinolytic systems in the patients' blood plasma, indicates that imbalance occurs only in MI patients.

The analysis of the linear correlation between the parameters showed that the relationship exists only in artificial plasma system in vitro activated by APTT reagent. Correlation analysis of the rela- 
$A$

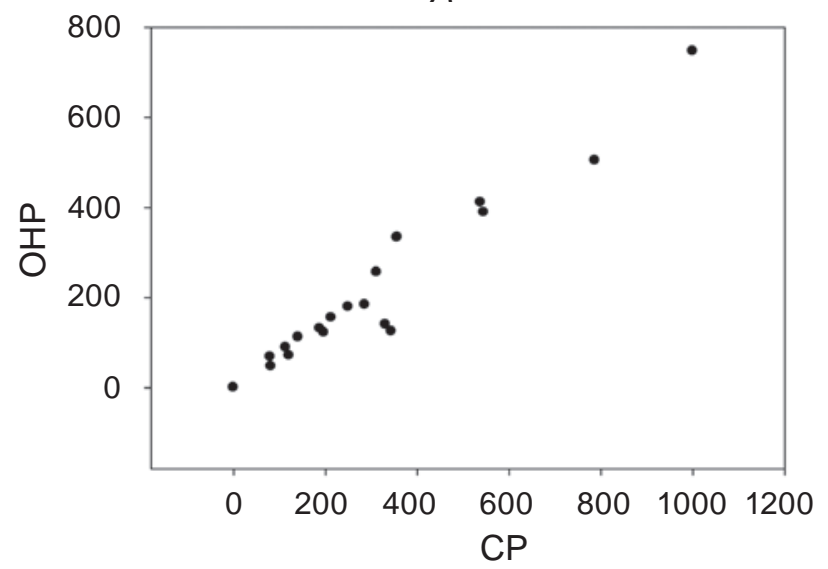

$B$

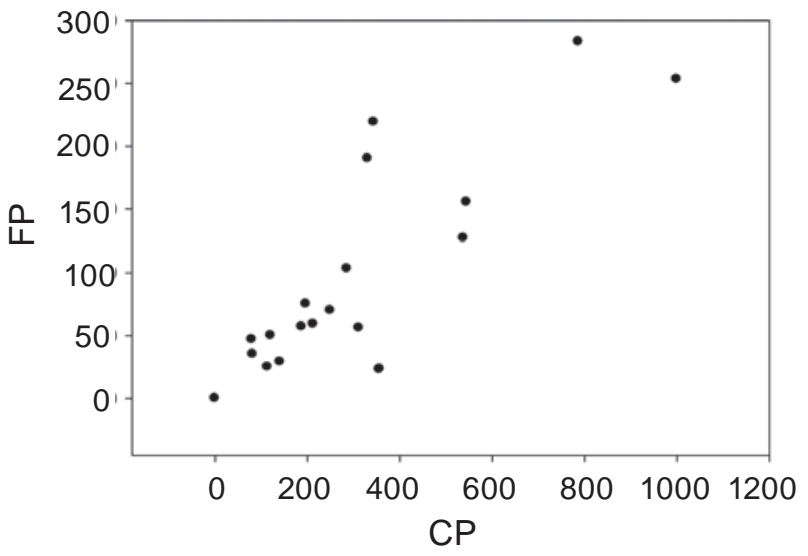

Fig. 5. Correlation between $C P$ and $O H P$ values (A) as well as $C P$ and FP values (B) for blood plasma of MI patients, correlation coefficients were 0.97 and 0.82 , respectively, $P<0.05$

$A$

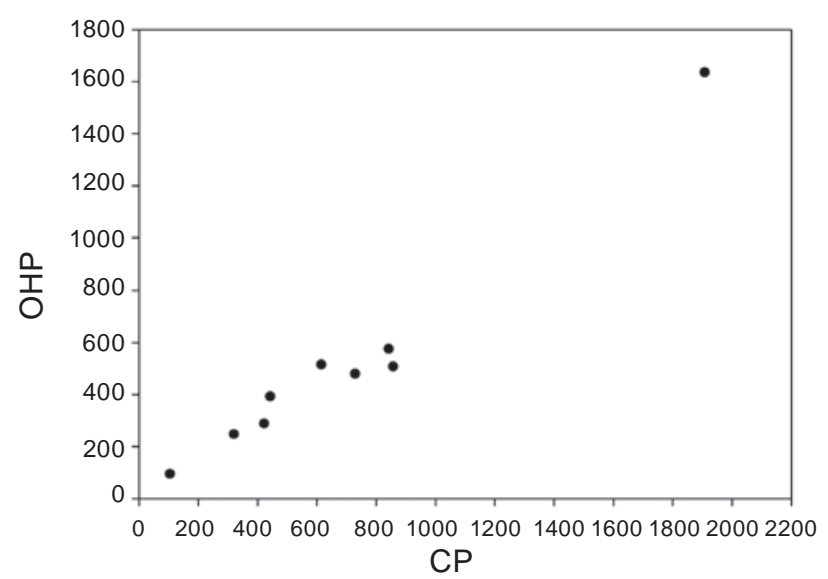

$B$

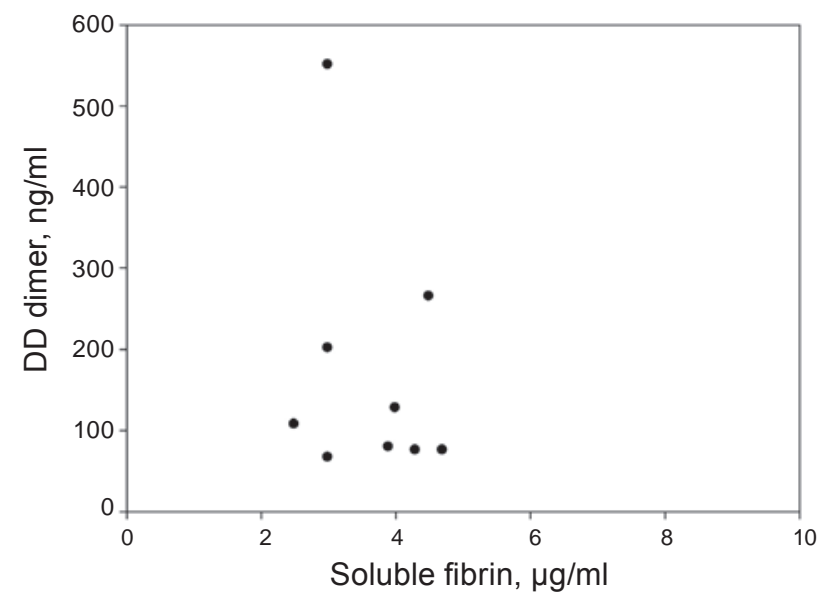

Fig. 6. Correlations between $C P$ and OHP values (A) and soluble fibrin and D-dimer values (B) for blood plasma of St patients; correlation coefficients were 0.98, $P<0.05$ and $0.25, P>0.05$, respectively

tionship between the concentrations of molecular markers formed in vivo, revealed only a weak relationship between the concentrations of Fg and soluble fibrin in the plasma of MI patients. Upon other diseases, the relationship between molecular markers formed in the hemostatic system in vivo, was not observed. Of note, there were no relationships between the parameters of system in vitro and in vivo. The obtained data suggest that the hemostasis parameters, which are determined in blood plasma in vitro using APTT reagent, cannot characterize the hemostasis processes in vivo, which are accompanied by the formation of soluble fibrin and D-dimer. 


\section{РІВЕНЬ ЗАГАЛЬНОГО ГЕМОСТАТИЧНОГО ПОТЕНЦААЛУ В ПЛАЗМІ КРОВІ ДОНОРІВ І ПАЦІЕНТІВ ІЗ ПАТОЛОГІЕЮ}

\author{
Л. В. Пирогова, Т. М. Чернишенко, \\ I. М. Колеснікова, Т. М. Платонова, \\ Г. К. Березницький, С. М. Макогоненко, \\ Е. В. Луговськой
}

\author{
Інститут біохімії ім. О. В. Палладіна \\ НАН України, Київ; \\ e-mail: ymakogonenko@gmail.com
}

Досліджували величини потенціалу зсідання (ПЗ), загального гемостатичного (ЗГП) i фібринолітичного потенціалів (ФП) у плазмі крові донорів і хворих на інфаркт міокарда (IM), інсульт (Ін) і захворювання тазостегнового суглоба (ЗТСС) за методом визначення глобального гемостазу M. Blomback. Зразки плазми крові хворих активували АЧТЧ реагентом за відсутності i в присутності t-PА. Було знайдено, що величини ПЗ, ЗГП і ФП у хворих по відношенню до таких у донорів становили відповідно за IM - за 78,60 і $123 \%$; за Ін - 157, 155 і 162\%; за ЗТСС 128, 131 і 124\%. Відношення величин ПЗ/ФП, що вказувало на баланс активності зсідальної і фібринолітичної систем у плазмі крові донорів і хворих на ІМ, Ін та ЗТСС, становило відповідно 4,13, 2,5, 4,0 і 4,26, що свідчило про підвищений рівень активності фібринолізу за ІМ. Лаг-період зсідання плазми у хворих на IM, Ін і ЗТСС був довше відповідно у 2,3, 7,2 і 1,5 раза. Аналіз кореляції між величинами потенціалів системи гемостазу, одержаних in vitro, і концентраціями молекулярних маркерів системи гемостазу-розчинного фібрину і D-димеру, - що утворюються в плазмі крові in vivo за IM, Ін і ЗТСC, зв'язку між цими величинами не виявив.

К л ю ч о в потенціал плазми крові, розчинний фібрин, D-димер.

\section{УРОВЕНЬ ОБЩЕГО ГЕМОСТАТИЧЕСКОГО ПОТЕНЦИАЛА В ПЛАЗМЕ КРОВИ ДОНОРОВ И ПАЦИЕНТОВ С ПАТОЛОГИЕЙ}

\author{
Л. В. Пирогова, Т. М. Чернышенко, \\ И. М. Колесникова, Т. Н. Платонова, \\ Г. К. Березничкий, Е. М. Макогоненко, \\ Э. В. Луговской
Институт биохимии им. А. В. Палладина НАН Украины, Киев; e-mail: ymakogonenko@gmail.com

Исследовали свертывающий (СП), общий гемостатический (ОГП) и фибринолитический потенциал (ФП) в плазме крови доноров и больных с инфарктом миокарда (ИМ), инсультом (Ин) и с заболеваниями тазобедренного сустава (ЗТБС) с помощью метода определения глобального гемостаза M. Blomback. Образцы плазмы крови больных активировали АЧТВ реагентом в присутствии и отсутствии t-PA. Было найдено, что величины СП, ОГП и ФП у больных по отношению к таким у доноров составляют соответственно при ИМ 78, 60 и 123\%; при Ин - 157, 155 и $162 \%$; при ЗТБС - 128, 131 и $124 \%$. Отношение величин СП/ФП, которое указывает на баланс активности свертывающей и фибринолитической систем в плазме крови доноров и больных ИМ, Ин и ЗТБС, составляло соответственно 4,13, 2,5, 4,0 и 4,26, что свидетельствовало о повышенной активности фибринолиза при ИМ. Лаг-период свертывания плазмы крови при ИМ, Ин и ЗТБС был дольше соответственно в 2,3, 7,2 и 1,5 раза. При анализе корреляции между величинами параметров системы гемостаза плазмы крови, полученных in vitro, и концентрациями молекулярных маркеров системы гемостаза растворимого фибрина и D-димера, - которые образуются in vivo при ИМ, Ин и ЗТБС, связи между этими величинами обнаружено не было.

Кл ю че в ы е с лов а: гемостатический потенциал плазмы крови, растворимый фибрин, D-димер. 


\section{References}

1. Antovic JP, Antovic A. Does recombinant factor VIIa, apart from overall hemostasis, regulate TAFI dependent fibrinolysis? In vitro analysis using overall hemostasis potential (OHP) assay. Thromb Haemost. 2003; 90(4): 620-627.

2. Antovic JP, Antovic A, He S, Tengborn L, Blombäck M. Overall haemostatic potential can be used for estimation of thrombin-activatable fibrinolysis inhibitor-dependent fibrinolysis in vivo and for possible follow-up of recombinant factor VIIa treatment in patients with inhibitors to factor VIII. Haemophilia. 2002; 8(6): 781-786.

3. Antovic JP, Antovic A, Sten-Linder M, Wramsby M, Blombäck M. Overall hemostatic potential (OHP) assay-a possible tool for determination of prothrombotic pattern in FXII deficiency. J Thromb Haemost. 2004; 2(11): 2058-2060.

4. Antovic A, Blombäck M, Bremme K, Van Rooijen $\mathrm{M}$, He S. Increased hemostasis potential persists in women with previous thromboembolism with or without APC resistance. J Thromb Haemost. 2003; 1(12): 2531-2535.

5. He S, Wallèn H, Bark N, Blombäck M. In vitro studies using a global hemostasis assay to examine the anticoagulation effects in plasma by the direct thrombin inhibitors: dabigatran and argatroban. J Thromb Thrombolysis. 2013; 35(2): 131-139.

6. He S, Antovic A, Blombäck M. A simple and rapid laboratory method for determination of haemostasis potential in plasma. II. Modifications for use in routine laboratories and research work. Thromb Res. 2001; 103(5): 355361.

7. Antovic A, Blombäck M, Bremme K, He S. The assay of overall haemostasis potential used to monitor the low molecular mass (weight) heparin, dalteparin, treatment in pregnant women with previous thromboembolism. Blood Coagul Fibrinolysis. 2002; 13(3): 181-186.

8. He S, Zhu K, Skeppholm M, Vedin J, Svensson J, Egberg N, Blombäck M, Wallen H. A global assay of haemostasis which uses recombinant tissue factor and tissue-type plasminogen activator to measure the rate of fibrin formation and fibrin degradation in plasma. Thromb Haemost. 2007; 98(4): 871-882.
9. Goldenberg NA, Hathaway WE, Jacobson L, Manco-Johnson MJ. A new global assay of coagulation and fibrinolysis. Thromb Res. 2005; 116(4): 345-356.

10. Antovic A. The overall hemostasis potential: a laboratory tool for the investigation of global hemostasis. Semin Thromb Hemost. 2010; 36(7): 772-779.

11. Mackman N, Taubman M. Tissue factor: past, present, and future. Arterioscler Thromb Vasc Biol. 2009; 29(12): 1986-1988.

12. Hedner U. General haemostatic agents - fact or fiction? Pathophysiol Haemost Thromb. 2002; 32(Suppl 1): 33-36.

13. Curnow JL, Morel-Kopp MC, Roddie C, Aboud M, Ward CM. Reduced fibrinolysis and increased fibrin generation can be detected in hypercoagulable patients using the overall hemostatic potential assay. $J$ Thromb Haemost. 2007; 5(3): 528-534.

14. Chernukha LM, Kashyrova EV, Lugovskoy EV, Komisarenko SV, Kolesnikov IN, Makohonenko EM, Platonova TN, Pirogova LV, Gornickaya OV. Characteristics of hemostatic system state at arteriovenous forms of congenital vascular malformations. Novosti Khirurgii. 2014; 22(2): 191-198. (In Russian).

15. Lugovskoy EV, Kolesnikova IN, Lugovskaya NE, Litvinova LM, Gritsenko PG, Gogolinskaya GK, Lyashko ED, Kostyuchenko EP, Remizovsky GA, Pedchenko VN, Komisarenko SV. Quantification of D-dimer and soluble fibrin in blood plasma at ischemic heart disease and hypertension. Ukr Biokhim Zhurn. 2004; 76(6): 136-141. (In Russian).

16. Rublenko AM. Urvant LP, Makogonenko YM. Platonova TN, Chernyshenko TM, Kolesnikova IM, Fishchenko VO, Lugovskoi EV. Effect of protein $\mathrm{C}$ activator on overall haemostasis potential in donor and hip arthroplasty patient plasma. Ukr Biokhim Zhurn. 2011; 83(5): 32-39. (In Ukrainian).

17. Carr ME Jr, Hermans J. Size and density of fibrin fibers from turbidity. Macromolecules. 1978; 11(1): 46-50.

18. Suenson E, Petersen LC. Fibrin and plasminogen structures essential to stimulation of plasmin formation by tissue-type plasminogen activator. Biochim Biophys Acta. 1986; 870(3): 510-519. 
19. Sakharov DV, Nagelkerke JF, Rijken DC. Rearrangements of the fibrin network and spatial distribution of fibrinolytic components during plasma clot lysis. Study with confocal microscopy. J Biol Chem. 1996; 271(4): 21332138.

20. Marder VJ, Francis CW. Plasmin degradation of cross-linked fibrin. Ann N Y Acad Sci. 1983; 408(1): 397-406.

21. Mihalyi E. Kinetics and molecular mechanism of the proteolytic fragmentation of fibrinogen. Ann N Y Acad Sci. 1983; 408(1): 60-70.

22. Suenson E, Bjerrum P, Holm A, Lind B, Meldal M, Selmer J, Petersen LC. The role of fragment $\mathrm{X}$ polymers in the fibrin enhancement of tissue plasminogen activator-catalyzed plasmin formation. J Biol Chem. 1990; 265(36): 22228-22237.
23. Makogonenko YM, Kirpa CA, Lugovskoi EV, Nasarenko HA, Kudinov CA. Kinetics of gluand lys-plasminogen activation by the tissue activator in a fibrin clot. Biokhimiia. 1987; 52(10): 1746-1752. (In Russian).

24. Hantgan RR, Hermans J. Assembly of fibrin. A light scattering study. J Biol Chem. 1979; 254(22): 11272-11281.

25. Makogonenko E, Tsurupa G, Ingham K, Medved L. Interaction of fibrin(ogen) with fibronectin: further characterization and localization of the fibronectin-binding site. Biochemistry. 2002; 41(25): 7907-7913.

26. Lenting PJ, Casari C, Christophe OD, Denis CV. von Willebrand factor: the old, the new and the unknown. J Thromb Haemost. 2012; 10(12): 2428-2437.

Received 19.11.2015 